\title{
Transformation of the role of financial analysis in enterprise management
}

The paper deals with the concept of financial analysis in the economic theory, identifies the role of financial analysis in management decision-making and suggests methods for its implementation. The successful economic development in modern conditions demands effective financial policy of each enterprise which is possible only when extensive financial analysis is accomplished. Therefore, it is important to use complex methods of financial analysis in order to manage an enterprise skilfully. The aim and the result of the paper is to put forward the methods of financial analysis, establishing its concept and necessity.

Keywords: decision-making, financial analysis, financial statements, management, methods.

Straipsnyje aptariama finansinès analizės sąvoka ekonomikos teorijoje, identifikuojamas jos vaidmuo įmonès valdyme ir sprendimų prièmime bei siūlomi jos vykdymo metodai. Sèkmingas įmonès vystymasis naujomis sąlygomis reikalauja efektyvios finansų politikos kiekvienoje įmonèje. Ši politika įmanoma tik tada, kai atliekama išsami finansinè analizè. Sumaniam įmonès valdymui svarbu naudoti kompleksinius finansinès analizès metodus. Šio straipsnio paskirtis ir tikslas yra pateikti finansinès analizès metodus, pristatant jų apibrèžimus ir ịrodant būtinumą.

Raktiniai žodžiai: sprendimų prièmimas, finansinè analizè, finansinẻ ataskaita, valdymas, metodai.

\section{Introduction}

Financial analysis has an important role in the changing economic environment. It helps in understanding of the correctness and efficiency of the use of financial resources in generating company earnings. Due to the analysis, an enterprise has an opportunity to evaluate its financial operations and market position, to identify possible risks, to notice mistakes and make plans for the future.
The topicality of the subject can be justified with the fact that, in the modern market conditions, the evaluation of company's financial position and operating efficiency can be regarded as part of the financial policy. Therefore, a skilful management of resources must be based on the results of financial analysis. The first problem is that the development of the economy is not possible without the efficient operations of each enterprise. The enterprise, in its turn, can operate with profit and provide

Elvīra ZELGALVE - Dr. oec. profesor; Finance Department, University of Latvia, Faculty of Economics and Management. Address: Aspazijas bulvāris 5, Riga, Latvia.Tel.: 0037167034 620. E-mail: elzelg@lanet.lv.

Anastasija ZAHARČENKO - Master student in Economics; University of Latvia, Faculty of Economics and Management. Customer service specialist, Danske Bank. Address: Aspazijas bulvāris 5, Riga, Latvia. Tel.: 00 37127030 264. E-mail: anastasia.zaharcenko@gmail.com. 
revenues to the state budget only if wellconsidered management is implemented, which is based on quality financial analysis, the evaluation of changes in indicators and factors influencing these changes. The second problem is that the existing methods of financial analysis are needed in some addition and their development, which is the demand of the modern market economy; it is necessary nowadays to create a universal and effective model for better business management. And the last problem is that there is still no common terminology for different notions in the economical theory, concerning financial analysis. These problems show that the role of this analysis is being transformed, is changing in favour of extension.

The object of the paper is financial analysis in enterprise management.

The aim of the paper is, based on the research of scientific and educational literature, to put forward the methods of financial analysis, establishing its concept and necessity.

In order to achieve the aim, the following tasks were nominated: to investigate the conceptual base of financial analysis; to determine the differences between similar notions that are connected with the term of financial analysis; to give an evaluation of definition of financial analysis; to determine the role of financial analysis in the economic theory; to investigate the influence of financial analysis in management decision-making; to work out the methods of financial analysis.

The research involves the use of following methods: a systematic analysis of scientific literature and documents, including comparison, synthesis and generalization, as well as graphic representation. The chosen methods help to achieve the aim of the paper and demonstrate paper's results.
The informative base of the paper is specialised economic literature, monographs and publications on financial analysis and financial management by Western and Eastern scientists, expert opinions, periodicals, papers and reports in management and investment portals on the process and necessity of the analysis, etc.

\section{Concept and substance of financial analysis}

Nowadays, the financial analysis of an enterprise is one of the main prerequisites for successful management of financial resources, and, according to several scientists, is one of the most significant elements of financial management. The efficient operation of a company requires economically well-founded management decisionmaking, which is based on the analysis of current operating and financing activities. In the classical understanding, financial analysis is the investigation of the main parameters, coefficients and multipliers, which provides an objective evaluation of company's financial position, as well as includes the analysis of company's share price with an aim of decision-making in the field of capital investing. However, there are different opinions on what is financial analysis exactly. It is necessary to point out that often this notion is referred to as financial statement analysis, and financial condition analysis (analysis of financial condition). To better understand whether these three notions can be used as synonyms, or if there are principal differences between them, the authors of the paper will provide the opinions of leading economists on this subject.

In the economically developed countries, a broad interpretation of the financial 
analysis is quite widespread. O. D. Bowlin, J. D. Martin and D. F. Scott (1990) write that financial analysis covers all stages of analytical activity in the field of financial management that are connected with the management of financial resources in the context of the surrounding environment, including the capital markets. The Western financial scientist L. A. Bernstein (2002) defines financial analysis as a process, the aim of which is to evaluate the current and past financial condition and the results of operations of an enterprise. $\mathrm{He}$ points out that the most important thing is to estimate and predict the conditions in the future and the subsequent operations of a company. The economist E. A. Helfert (2003) believes that financial analysis is a research, as well as a process that assists in answering questions that arise in the course of company management.

The widely-known U.S. economists W. F. Sharpe, G. J. Alexanderand J. V. Bailey (1998) give a different approach to financial analysis by narrowing down its scope, giving attention only to financial market indicators.

Russian financial analyst I. Blank (Бланк, 2004) interprets financial analysis as the investigation of company financial position and main results of financial activity to ascertain the reserves of increases in market value and to ensure effective development of the enterprise. The scientist O. Efimova (Ефимова, 2012) links financial analysis with the process that is based on the investigation of data (indicators that characterise organisation's financial position and the efficiency of activity in the past) with an aim to evaluate company development prospects.

Consequently, by investigating the opinions of leading economists from different countries, one may conclude that the majority of scientists interpret the notion of financial analysis in roughly the same way, with the differing views belonging to W. F. Sharpe, G. J. Alexander and J. V. Bailey (1998), which is understandable because their main aim is to analyse financial markets.

Some finance experts identify "financial analysis" with the "analysis of financial condition", and use the terms as synonyms in their research. Thus, for example, the professor of economics V. Kovalev (Ковалёв, 2000) points out that in the traditional sense financial analysis is a method of evaluation and prediction of the financial position that is based on corporate financial reports. His colleague I. Balabanov (Балабанов, 2002) has concluded that financial analysis is a method of evaluating the retrospective and prospective company financial position that is based on the mutual dependence and dynamics of the financial indicators. At the same time, professor notes that financial analysis is a profound, science-based research into financial relationships and flows of financial resources in the process of company operations. Other Russian economists, for example, I. Sannikova, V. Stas, O. Ergardt (Санникова, Стась, Эргардт, 2003) regard financial analysis and analysis of the financial condition as the same thing defining financial analysis as a process, as a result of which the current financial position is evaluated.

However, as was determined during the period of writing this paper, several authors - both Western and Eastern - separate the two notions and define the analysis of financial condition as part of the analysis of operations or financial analysis. This opinion is widespread and, for example, Russian financial specialist N. Rusak (Русак,1999), by closely investigating the 
matter, has arrived at a competent conclusion that financial analysis has a broader interpretation since it involves the analysis of financial condition (the ability to finance its operations), analysis of earnings formation and distribution, the analysis of production costs, as well as questions related to marketing activities, the possibilities to improve company activities etc. The same opinion is expressed by the widely known economists E. F. Brigham and L. C. Gapenski (1997). Moreover, in their publications they point out that the content of financial analysis depends on the aim of research, and taking into consideration the aim, one must choose whether it is necessary to conduct the complex analysis of strengths and weaknesses of the company, or, for example, the relatively simple analysis of current liquidity.

The authors of the paper, after a diligent investigation of this question, also believe that the equalisation of the notions of financial analysis and analysis of financial condition is not well-founded. The concept of financial analysis is much wider; therefore these terms can not be used as synonyms. The notion of the analysis of financial condition means the evaluation of company ability to finance its operations, while financial analysis in addition includes the comparison of company financial indicators with competitor equivalents and average indicators for the whole industry, prediction, the analysis of changes in stock prices, the analysis of economic conditions, and much more. Therefore, the notion of financial analysis is used to emphasise the broad nature of analytical procedures in the research.

Often one encounters the notion of financial statement analysis in the economic literature. This term emphasises the role of information base (company annual reports) in the implementation of financial analysis because the main information necessary for the analysis is gathered from the reports.

The English version of Wikipedia interprets the Financial statement analysis as the evaluation of company viability, stability and profitability, and under this term Wikipedia understands the Analysis of accounting reports and Financial analysis, as well.

The Asian financial scientist R. Javed (2009) also uses the notion of Financial statement analysis in his publications on the grounds that the analytical work in question involves information from different financial reports with the primary aim being the ability to predict company "financial health".

The term of financial statement analysis is often used by many foreign economists. In periodicals such as "Financial Analysts Journal", "European Journals of Scientific research", "The Wall Street Journal", "Journal of Business Finance and Accounting" etc., it can be found more often than the two previous notions (financial analysis and analysis of financial condition) but in essence its meaning is the same as financial analysis. Therefore, they can be used as identical, however, the authors of the paper believe that using the notion of financial statement analysis is not quite correct because according to the definition one can imagine that one evaluates the structure and contents of financial reports, methods of information presentation, quantity etc. In addition, it reflects to a lesser extent the main aim of analysis management decision-making. Therefore, the authors of the paper have arrived at a conclusion that financial analysis is the most appropriate title for this paper. 
One must note that there are differing approaches to the place of financial analysis in the economic science. Some economists believe that it is an important part of financial management, others - that financial analysis is a separate science. Among the advocates of the first approach there are several economists, both Western - J. C. Van Horne (1996), E. F. Brigham and L. C. Gapenski (1997), E. A. Helfert (2003), P. Atrill (2006) etc., as well as Eastern - V. Kovalev (Ковалёв, 2002), I. Blank (Бланк, 2004), G. Polyak (Поляк, 2009), E. Borodina (Бородина, 2011), etc.

For example, the professor of economics V. Kovalev (Ковалёв, 2002) believes that financial analysis must logically be interpreted not as a separate branch of science but only as an element, yet an important element, of the financial management system. He explains this approach with the impossibility to separate management functions - analysis is important not in itself but only as an integral part of effective management system. Financial analysis is used only in order to make a management decision. This opinion is supported by professor G. Polyak (Поляк, 2009) noting that financial analysis is a significant element in corporate financial management, as well as in the formation of economic relations with partners, financial and loan system. They are joined by assistant professor E. Borodina (Бородина, 2011), who asserts that analysis is an instrument of financial management designed for wellfounded management decision-making. The American scientist P. Atrill (2006) also recognizes that financial analysis exists in order to help company management in their duties, to work out longterm plans and make everyday decisions, to control company operations and risks. Therefore, he asserts that it can not be a separate science. E. A. Helfert (2003) is of the same opinion, adding that financial analysis provides an effective support in operational company management. However, as mentioned before, there is another approach to this question. Some scholars believe that financial analysis is a separate science and that problems of financial management and problems of conducting financial analysis should be considered separately. Thus, for example, doctor of economic sciences A. Zhilkina (Жилкина, 2005) in her dissertation has made a detailed study of this question, and based on the works of B. Venturi, I. F. Sher, P. Herstner, as well as R. Sheremet, E. Sayfulin and others, has concluded that financial analysis is a separate science which started to emerge in the $17^{\text {th }}$ century, and became a separate branch of science in the sixties of the last century. To their mind, financial analysis is a social science that is linked to other sciences (natural and technical) and analyses financial resources and their flows on a state-wide - macro-level, and in each enterprise separately - micro-level. Another Russian economist G. Liferenko (Лиференко, 2005) sets economic and financial analysis on one level, recognizing the latter as a separate branch of science.

After an examination of the subject, the authors of the paper will interpret financial analysis as an element of financial management agreeing to the scientists of the first group, justifying our choice with the fact that the main users of financial statement analysis - company administration - use different methods of analysis mainly to successfully manage financial resources of the company. It is also sought after among creditors and investors, in 
courts and other state institutions to make well-founded decisions (granting of loans, investment decisions, implementation of court judgements, observance of state interests etc.). The main goal of financial management is to maximise company owners' wealth.

Financial statement analysis is part of financial management (corporate finance, arguably managerial accounting), as well as part of the fundamental analysis of financial markets. This relationship can be described in the figure 1 .

Based on the works of aforementioned authors on the concept of financial analysis one can discern the following tasks of financial analysis:

- to evaluate company's current and potential financial condition, as well as efficiency and activity;

- to ascertain the changes of financial indicators and to find out the reasons of the changes;

- the identification and targeted mobilization of the accessible resources;

- the evaluation of potential and targeted company growth rate;

- the prediction of company position in capital market;

- to detect the possibilities of improving the company operations.

The authors of the paper set out with a task of formulating the main aim of financial analysis, which sounds as follows - to ascertain the information on the company's financial condition to make appropriate decisions.

To achieve the aforementioned aim, financial analysts, managers, auditors, accountants etc. must solve several tasks, for example:

- to get acquainted with the accounting reports;

- to analyse company assets and sources of financing;

- the analysis of financial stability and solvency;

- the analysis of activity;

- the analysis of earnings and profitability;

- the analysis of market value;

- the analysis of cash flow;

- the prediction of the financial condition;

- to prepare conclusions and management recommendations, decisions etc.

In a nutshell, the tasks of financial analysis are as follows: to determine, which parameters of company's activity are satisfactory, and therefore, can remain at their current levels, and which parameters are unsatisfactory and demand an urgent adjustment.

Thus, one can conclude that financial analysis is made of three interrelated parts:

\begin{tabular}{|c|c|c|c|c|}
\hline \multirow[b]{2}{*}{$\begin{array}{l}\text { Financial } \\
\text { accounting }\end{array}$} & \multirow[b]{2}{*}{$\begin{array}{l}\text { Financial } \\
\text { management }\end{array}$} & & \multirow[b]{2}{*}{$\begin{array}{l}\text { Funda- } \\
\text { mental } \\
\text { analysis of } \\
\text { financial } \\
\text { markets }\end{array}$} & \multirow{2}{*}{$\begin{array}{l}\text { Technical analysis } \\
\text { offinancial } \\
\text { markets }\end{array}$} \\
\hline & & $\begin{array}{l}\text { Financial } \\
\text { statement } \\
\text { analysis }\end{array}$ & & \\
\hline
\end{tabular}

Fig. 1. The place of financial statement analysis in economic science 
- the analysis itself - in this case, a logical approach to evaluation of company financial activities;

- synthesis - a unification into one of elements divided before;

- the putting forward of measures to improve company's financial activity.

\section{Methods of conducting financial analysis}

When investigating the concept of financial analysis, one must review how to conduct it; therefore, next we deal with the methods of implementing financial analysis. With the term "methods" authors understand an aggregated notion, which involves different models and methods for conducting financial analysis. All of the terms are linked to the practical side of financial analysis.

In the process of preparing for the analysis, the main thing is to work out such models and methods that allow to form structures and to identify the linkage between the indicators, as well as to implement analysis by looking at several pieces of data. Nowadays, the base of management and investment decisions are models that involve not only analysis of financial indicators but also the analysis of indicators linked to credit risks, as well the prediction of future operations etc. Therefore, the authors of the paper will look more closely at today's methods and models of financial analysis.

There are three main types of models in modern teaching and scientific literature: descriptive, normative and predicative (Ковалёв, 2002) Descriptive models are the basic models that are based on the use of accounting information and help to evaluate the corporate financial position.
They involve the construction of system of balance sheets, the system of analytical ratios, horizontal and vertical analysis etc. Predicative models are forecasts, and use mathematical and statistical methods, as well as programming to predict company revenues and financial position. In their turn, normative models compare the actual results of company operations with expectations that are calculated according to the budget. Normative models are used in internal management of the enterprise to analyse the differences between normative and actual data, especially for each item of costs. Taking into consideration the role of every method, the authors of the paper have created the methodology of financial analysis, which can be reflected graphically (Fig. 2).

To the authors' minds, when conducting financial analysis, the most important are the methods of the descriptive model because they involve the analysis of the past operations, and based on this, the forecasts and future plans are carried out. The methods of this model will be looked at in more detail.

The reading of accounting report is necessary as a general familiarization with company's financial condition using the profit or loss account, the balance sheet and the cash flow statement. This method allows acquainting oneself with company property, nature of operations, the structure of assets, equity and liabilities.

Horizontal analysis is conducted by calculating and comparing the relative and absolute changes of items of different reports.

Several economists recognize that the horizontal method is useful because it helps in quick determination of how the financial position of an enterprise has changed over time. Thus, for example, 


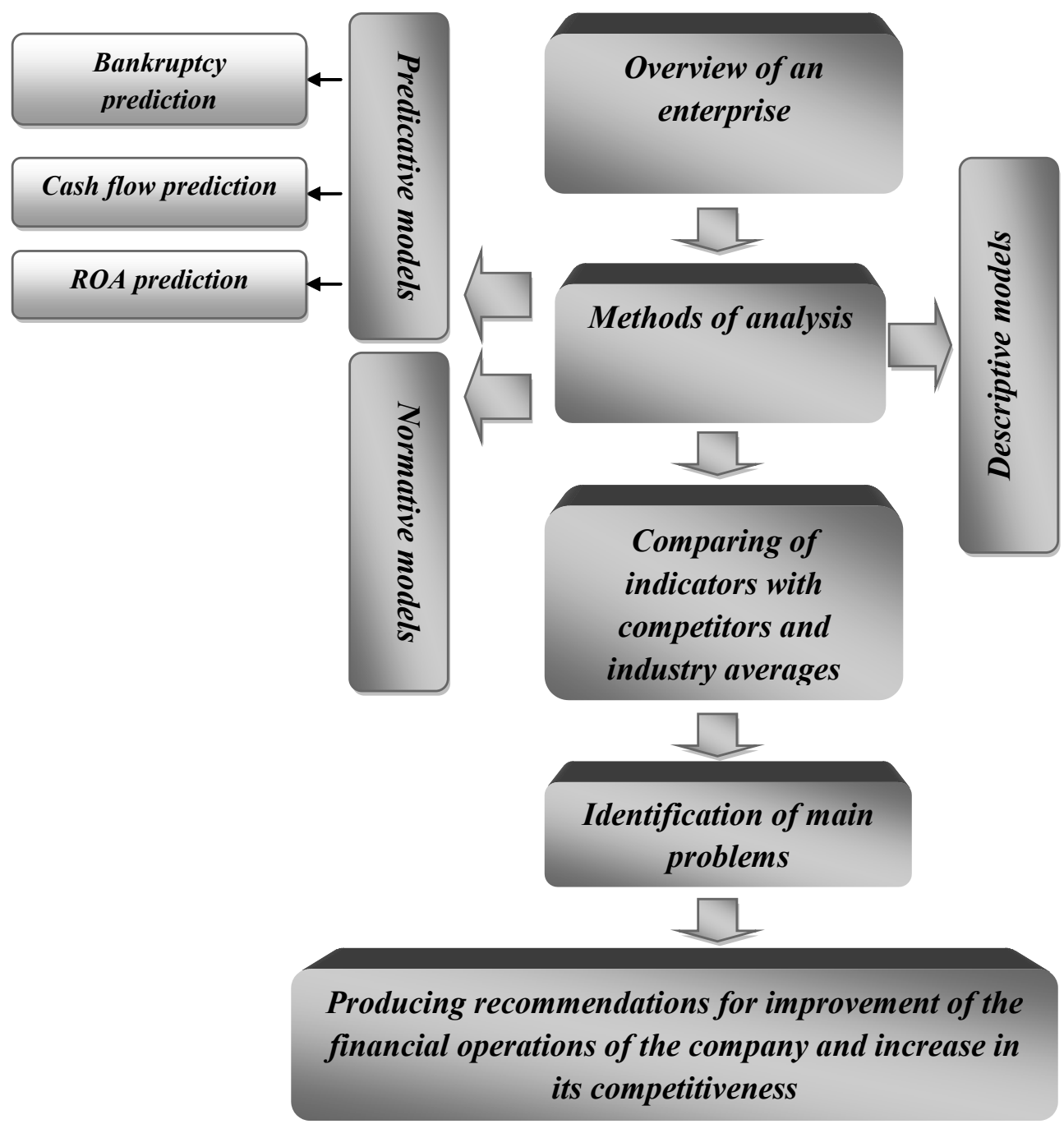

Fig. 2. The methods of conducting company financial analysis

Source: Figure created by the authors of the paper.

U.S. financial expert A. Kulkarni (2012) states that this method helps users of financial statements to follow the trends of separate items, and notes that, to understand whether company position improves or worsens, you do not have to be a financial expert. U.S. accounting scientist M. Bushman (2007) believes that the horizontal analysis in necessary to find out whether the company is too conservative or too excessive in terms of costs, as well as to compare small enterprises with large organizations.

However, economists recognize also that this method has its drawbacks. For example, financial specialist E. Novopashina 
(Новопашина, 2008) writes that the value of results of horizontal analysis decreases because of inflation, however, she emphasises that this problem can be avoided with revaluation of data.

The vertical analysis is the determination of structure of aggregate financial indicators, with an emphasis on the impact of every position on the aggregated result. This method allows the recognition of changes in both sides of enterprise balance sheet, as well costs by comparing the data over several periods.

Scientist V. Kovalev (Ковалёв, 2002) points to two main features of why it is useful to conduct vertical analysis: the possibility of comparing companies and avoiding the effect of inflation. Financial scientist J. Clausen (2010) states that for quality analysis the vertical analysis method should be used alongside the horizontal method. They complement each other, and therefore, it is usual to compile analytical tables that characterise the structure of accounting report, as well as the dynamics of separate items.

Taking into consideration the aforementioned, the authors can conclude that both these methods are especially useful in comparing companies because they allow evaluating and comparing enterprises with divergent volume of sales and different operations. However, they give just the first impression - a generalised description of the financial activities of the company.

Trend analysis involves comparing of every item in the report with previous periods, and establishing a trend. Trend method is used when it is necessary to come up with forecasts of indicators. This method of analysis is classified as a kind of horizontal analysis, which is used when it is necessary to compare items over more than three years. However, in some economic papers the trend analysis is identified with horizontal (Accounting for managers, 2011). The authors of the paper believe that this equating is essentially acceptable, however, the notion of trend analysis emphasises the main idea of the method, and therefore, it would be correct to use the definitions separately.

Comparative analysis involves comparing indicators with competitors and with the average indicators in the respective sector of industry. This kind of analysis is one the most important because it gives an overview not only of how the company looks compared to previous periods but also compared to similar enterprises. Thanks to the method, one can clearly evaluate the company position in the market because even a good internal financial position may look poor when compared to the sector of industry.

Factor analysis is used to investigate and evaluate the impact of different factors on the results of company performance. It can be direct when indicators are split into constituent parts, and also it can be backward when separate elements are joined into an aggregated indicator. Factor analysis may be one-stage when factors of one level are used in the analysis, and it can be multi-stage when factors are divided into separate elements to research their behaviour. It can be retrospective investigates the results' growth in previous periods, and prospective - analyses the behaviour of factors and results in the future etc.

Economists A. Balzhinov and E. Mikheeva (Балжинов, Михеева, 2012) assert that factor analysis allows the researcher to solve two tasks: to describe the indicator in question in a compact, yet versatile way. With the help of this 
analysis it is possible to detect factors that determine correlation linkage between the observed indicators. Financial scientist M. S. Siddiqui (2007) states that with the aid of factor analysis one can clarify the elements that have influenced company earnings, therefore, one can predict future returns. U.S. marketing scientist K. Lorette (2012) affirms that factor analysis is important also for those in the field of marketing because the results of factor analysis can change the way of presentation of company products. The authors of the paper also believe that factor analysis plays a special role in conducting company financial analysis as a whole. The determination of impact of different factors on the end results can significantly influence the management decisions, therefore, in order for the decisions to be well-founded and reflect the current situation the entrepreneurs must turn a greater attention to this question.

For an integrated financial analysis it is necessary to perform also the cash flow analysis to get an understanding of the ability of the company to generate cash. Some economists believe that cash flow analysis is of the uppermost importance. There are cases when there is a positive conclusion on the company's financial position but shortly afterwards it turns bankrupt. T. A. Lee, R. W. Ingram and T. P. Howard (1999) have discovered in their paper that earnings are significantly greater than operating cash flow in enterprises in which fraud and distortion of financial report data had been detected during the next year. It points out the fact that cash flow is an important signal in this sense. The research of A. Cheng and S. S. M. Yang (2003) has also provided evidence on the importance of operating cash flow found in the financial statements. In the papers in „Experts Column”, there are views of some economists on the functions of cash flow statement and there has been emphasis on its usefulness in planning financial operations because, to their opinion, the main aim of this statement is to provide managers with information, which helps in business management (Experts Column, 2009).

Latvian scientist K. Subatnieks (2007) states, that cash flow analysis is especially useful to creditors and investors. For example, operating cash flow indicators could help them to estimate the ability of the company to generate money from its operations, as well as to cover loan payments and interest payments. $\mathrm{He}$ also stresses that creditors and investors are more interested in future cash flow, its volume and time when it will be received, because even a successful company can become insolvent if does not have adequate cash flow available to pay its bills.

U. S. journalist S. Hotmann (2011), in a compilation of financial expert opinions, notes that cash flow analysis has a great role during the times of economic instability when entrepreneurs must give a lot of attention to fixed and unforeseen costs and must make reserves of cash to survive in foggy times. One can not argue with that.

However, the majority of research concentrates on the complementary role of cash flow. Thus, economists C. D. B. Clubb (1995) and S. McLeay, J. Kassab and M. Helan (1997) state that cash flow gives additional information to the earnings of a company. In the internet portal "E-how money" (2012) one can come across an opinion that cash flow simply shows what amounts of money flow in and flow out of the company, and if, for example, a company is selling products below their cost, 
irrespective of the fact that there is a cash inflow and operating cash flow improves, one can not say that the company operates effectively because this is not lucrative.

However, the authors of the paper believe that cash flow analysis is also an important part of financial analysis because it can help in evaluating company's financial flexibility - the ability to generate adequate cash to react in time to unexpected needs and opportunities, as well as helps entrepreneurs to predict their financial position in the near and far future. The cash flow analysis and prediction is especially useful for companies with high capital intensity. So, one can confidently state that in order for the financial analysis to be well-founded, it is necessary to evaluate the cash flow statement, interpret its items, and based on the results, make the required decisions depending on interests.

The most popular method of financial analysis right now is calculation of analytical ratios. It involves the calculation of ratios of financial statement data and establishment of the mutual relations of indicators. Financial ratios are used by all the persons interested in company's financial condition to establish its financial position and performance. Referring to the opinion of the economist R. O. Igben, one can say that the analytical ratios method is one of the most powerful tools used in conducting financial analysis and the interpretation of results. Scientist W. $\mathrm{R}$. Lasher is of the same opinion, stressing that with the help of financial ratios it is most convenient to compare indicators of a particular company with industry-wide averages and competitor indicators. However, the ratios themselves are hard to interpret unambiguously. Financial scientist R. H. Hermanson also believes that ratio analysis is the most significant method in completing an integrated financial analysis but notes that to get a better apprehension of company activities, it is necessary to calculate several interlinked coefficients (Uzochukwu, 2010).

Russian economists L. Basovskiy, A. Luneva and A. Basovskiy (Басовский, Лунёва, 2005) also note the significance of the ratio method and highlight five advantages of the method: it gives information that is necessary to all the users of financial analysis, it allows identifying the trends of changes in financial position, gives an opportunity to evaluate company operations compared to the competitors, removes the influence of inflation, ratios can be calculated in a quick and relatively simple way. The scientists add that to conduct analysis of the highest quality it is necessary to calculate a relatively large amount of ratios. Financial ratios have their drawbacks too, for example, they provide information only about the past, they can not be interpreted unambiguously, however despite some faults, they provide with clear and deep enough overview of company operations.

Based on a wide-range of literature, one can conclude that several Western and Eastern scientists are united with a common approach to the evaluation of corporate financial position using the method of analytical indexes. This approach is based on different coefficients, with the number ranging from fifty to two hundred. However, there are economists that try to reduce the number of ratios to a minimum (Мухаметшин, Антипов, 2011). The authors of the paper want to stress that the main thing is the ability to adequately uncover the dynamics of the financial condition un to determine reasons behind the changes, not the number 
of ratios, and one must use as many coefficients in the analysis as is necessary to achieve the aim of the analysis.

As mentioned before, there are very many different analytical ratios that are divided into several groups. The authors of the paper put forward five categories of ratios - liquidity, profitability, asset activity, financial stability and capital market position. The groups are investigated in more detail below.

1. Liquidity ratios show the ability of an enterprise to transform different assets into cash in relatively short time. Company liquidity is of interest to several groups of users of analysis, especially creditors to ascertain that the loan will be paid back. The liquidity ratios of a company allow the evaluation of assets, however one must be careful with liquidity analysis because growth in liquidity can be a negative, as well as a positive signal.

2. Profitability ratios reflect the evaluation of aggregated efficiency of investment; therefore, they are the most important ratios for owners and management. Maximizing earnings is in the interests of every entrepreneur, and profitability ratios are the ones that answer the question whether their business is on the right track.

3. Asset activity ratios show the efficiency of the management of company property. This group of ratios consists of turnover coefficients of total assets, current assets, inventory and accounts receivable. The evaluation of activity ratios in the period in question helps in understanding whether assets productivity has increased, or declined. If, for instance, assets have started to have a slower turnover, this could be a sign of problems with asset management in the company.

4. Analysis of financial stability (capital structure) allows evaluating the constituent parts of company financing sources (equity and debt). These coefficients are especially useful when the possibility of corporate insolvency is evaluated; therefore, creditors and suppliers prefer companies with high proportion of equity and greater financial independence. It is widely acknowledged that equity to debt ratio is strongly dependent on the sector of industry the company is operating in.

5. Financial market ratios characterise the corporate financial position and the value of shares. This is characterised by several ratios: earnings per share (EPS), dividends per share (DIV), price to earnings ratio $(\mathrm{P} / \mathrm{E})$, price to book value ratio (P/B) etc. All these ratios help company management understanding the regard of investors towards the operations of the company. If the ratios mentioned above liquidity, financial stability, profitability and activity are in order, then financial market ratios tend to be high and in most cases the share price will be on an upward trend.

Thus, for example, U.S. financial scientist R. Saylor (2008) writes that, if a company has a high $\mathrm{P} / \mathrm{E}$ ratio, it means that investors believe that the company has growth potential; of course, it influences investment decisions.

Professor S. Krylov (Крылов, 2010) writes that analysis of market activity of a publically-traded company is one of the most important components of company's business because it includes the choice of optimal strategies of earnings accumulation and distribution, and tactics of share issues.

In modern market conditions, one can regard the evaluation of company financial position and efficiency of operations as one of the branches of financial policy; therefore, the main task of companies is to switch to quality financial management, 
which is based on the results of financial analysis according to the market conditions. Up-to-date qualified analysis needs transformation and unification of existing methods, taking in consideration former and present results, with the purpose of foresting and making better the future.

Therefore, there was made a detailed layout of descriptive model, which is based on the above stated information (Fig. 3).

The authors of the paper offer the usage of such methods of the descriptive model: the "reading" of accounting reports, horizontal and vertical analysis of different indicators, analysis of financial ratios (financial stability, activity, liquidity, profitability), financial market analysis, factor analysis; the predicative model (bankruptcy, cash flow and capital profitability prediction); and the normative model. As mentioned above, with the help of normative models, the actual results of company operations are compared with expected results that are calculated according to the budget data, therefore, large companies must give greater attention to this model because it allows to determine whether the plan is being implemented.

To characterise company's financial activity, in the beginning, the authors of the paper put forward the necessity to acquaint oneself with the financial reports to get an overview of company operations and to perform the horizontal and vertical analysis of balance sheet and profit or loss account (in relative and absolute numbers) to evaluate the dynamics and amounts of the items. Afterwards, the analysis of financial ratios should be carried out that will give information in more detail on company performance and financial position. Ratios that are compared in a certain period of time help to determine whether company performance has relatively improved or worsened, allow ascertaining the productivity compared to a sector of industry, and the level of market competition.

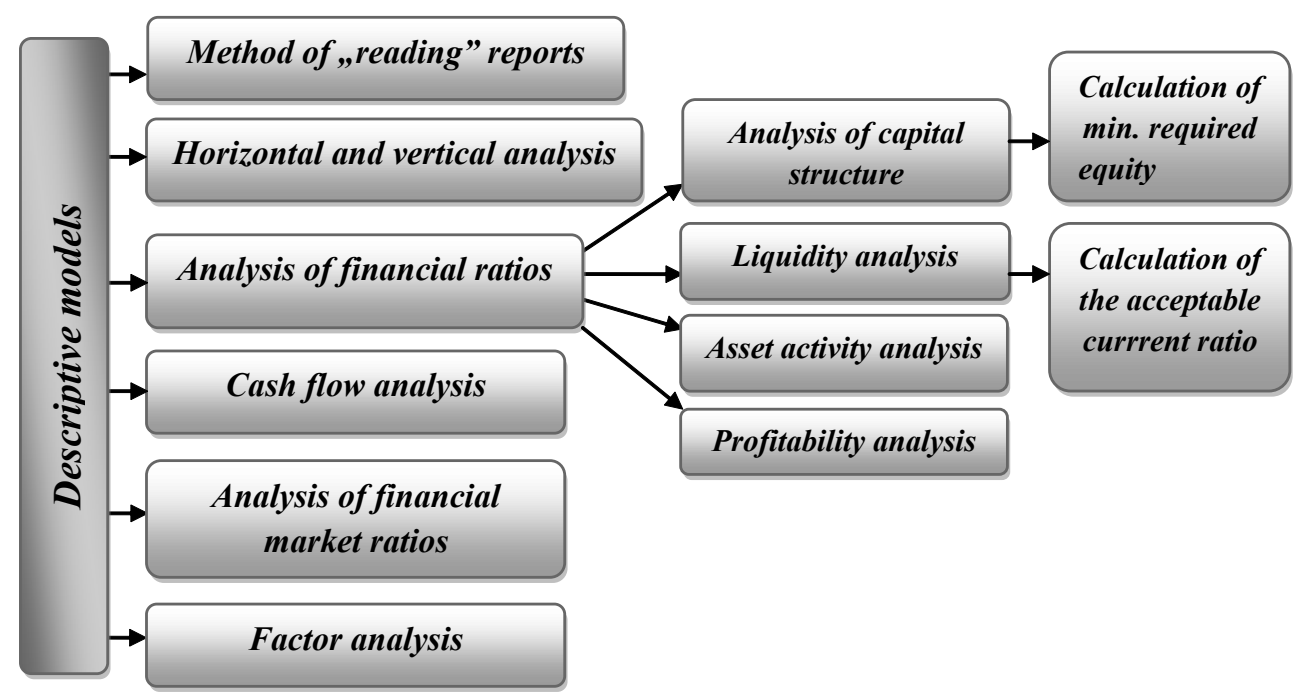

Fig. 3. The descriptive methods of conducting company financial analysis

Source: Figure created by the authors of the paper. 
The authors of the paper want to note that modern financial analysis demands to evaluate not only the dynamics of actual financial ratios but also to determine the acceptable level of these indicators - a limit that must not be breached because financial condition then could become critical. To our mind, here greater attention must be turned towards analysis of capital structure and liquidity because they show company's financial position, the asset value and the ability to pay off debt. To calculate the acceptable level of equity, one must follow the basic principle of financial management - equity must finance assets of low liquidity - long-term assets and current assets of low liquidity.

Minimally acceptable level of equity = Assets of low liquidity

Capital structure ratios reflect the sector of industry a company is operating in, and taking into account the specifics of each sector, there will be a different level of acceptable ratios. Therefore, according to the sector of industry, every company will have individual levels of acceptable current ratio. To calculate the acceptable current ratio, a following equation is put forward:

\section{Acceptable current ratio $=$}

Current assets (actual)

\section{Short-term debt (acceptable)}

The level of acceptable (not actual) short-term debt can be determined by subtracting current assets of low liquidity from current assets. Current assets of low liquidity must be financed from equity.

The authors of the paper state that the main thing is not the determination of actual financial ratios but it is the comparison with acceptable ratios, and the understanding of how far the company's position is from the critical indicators or "the red line". This comparison allows evaluating the situation in real terms and how close are the critical indicators, which, in its turn, allow discovering problems and identifying the necessity to make corresponding decisions to avert them.

The authors of the paper believe that next it is necessary to investigate also the cash flow statements that show the ability of an enterprise to generate cash. Afterwards, it is logical to carry out the analysis of financial market ratios to understand how the company operations are being viewed by the securities market and what is the attitude of investors towards the current and prospective operations of the company. This kind of analysis is distinguished separately by the authors of the paper, because it differs from analysis of other ratios - financial market ratio analysis takes into account not only the internal but also external factors, which respectively increases the value of this method.

Further, it would be appropriate to conduct the analysis of factors influencing earnings to get the understanding of which factors influence profitability indicators in a positive way, which - in a negative way; in other words, how price, cost and volume changes have influenced earnings and return on sales (ROS).

By evaluating the gathered information, one must come up with forecasts of the probability of bankruptcy, cash flows, and return on assets (ROA) for the following years to get a real outlook of possibilities of company development (View Fig. 2.).The forecasts will allow the management to correct its actions (investments in assets, costs etc.), get an idea of own competitiveness, as well as make the right management decisions and give an 
opportunity to work out a plan of measures for improving the performance of the company. One of the prerequisites of successful business is its solvency and the accessibility of financial resources; therefore, the methods include the analysis of probability of bankruptcy. Nowadays, there is a great variety of bankruptcy prediction models. The model must be chosen taking into consideration the specifics of company operations, the development level of state's market economy etc. To choose the appropriate model, one can use the research of the economist R. Shneidere (2009) on the systems of insolvency prediction methods, which may help finding the most precise model for measurement of the possibility of bankruptcy.

Cash flow prediction also is an important element of financial analysis because it gives company management and other users the information on the amount, timing and uncertainty of company future cash flows, as well as helps evaluating the impact of indicators of financial statements on the determination of company future cash flows. Cash flow prediction is especially important to companies that are in the phase of primary development and growth, when the demand for money is the highest.

For the forecasting of the company's ensuing activities, the analysis of ROA is chosen because in contrast to the rest of profitability ratios, it provides an aggregated overview of efficiency of company operations for the period of the analysis. $\mathrm{ROA}$ is a composite ratio, which depends on the ROS and ratios of asset activity; therefore, it is one of the most important profitability ratios. The return on capital (assets) shows the amount of earnings that the company has managed to get on one lat of assets regardless of the sources of financing, therefore, it is more convenient for comparing one company with another, and it shows company competitiveness more precisely. In practice, to come up with short-term forecasts of economic indicators, adaptive mathematical models are often used - Brown's and Holt's models that describe the development of the process as a linear tendency with parameters that change all the time (Бланк, 2004). For ROA forecasts, the authors of the paper offer using the Brown's model because it is a separate variation of the Holt's model, and allows acquiring a good prediction of the trend. One must add that the Brown's model can show the development not only in a linear way, but also as a random walk and a parabolic trend, therefore, three Brown's models can be distinguished - zero degree, first degree and second degree (Федосеев, Гармашидр, 1999). For forecasting return on assets (capital), the method of the first degree is advisable. The degree of precision of prediction models declines over time in the changeable economic environment, so to come up with a concrete and deliberate forecast, as well as to reduce error, the authors offer predicting ROA and bankruptcy two years ahead.

For an integrated evaluation, next one must compare the company ratios with competitors and industry averages because this kind of analysis will show the degree of competitiveness of the company.

The authors of the paper believe that the methods chosen will help clarifying the situation and will allow coming up with the right conclusions, which later on will guide to the necessary decisions. Taking into the consideration the calculations, one can evaluate the current financial position and performance of an enterprise, evaluate the outlook, and come up 
with the right conclusions on the financial activity of the enterprise. Based on conclusions, it is possible to put forward recommendations for the improvement of company performance and competitiveness, thereby, reaching the main aim of financial analysis.

\section{Necessity of financial analysis in company management}

According to the information above, the aim and tasks of financial analysis, one can conclude that it has an important role in successful operations of a company. Financial analysis is the basis for a profitable business - using analytical instruments and methods, one can determine significant relations and features that are necessary to make management decisions.

The data acquired during the analysis process help clearing the mind for decision-making and working out a plan of action in each case. The data give an opportunity to detect whether there is a relative improvement or worsening of company performance, whether the demand for manufactured goods and offered services complies with the supply, the resources invested, costs etc. The data from the analysis allow the marking of the main problems, to which attention must be turned to by the company management be it the slow asset activity, insufficient controls of accounts receivable, low or excessive liquidity etc. Therefore, company management may be aware that it is necessary to change the current credit policy, pricing policy or marketing policy, or a restructuring is needed, and by the means of regular financial analysis, one can identify the most useful measures that ensure the successful company performance.
The role of financial analysis in making operational decisions is emphasised by several scientists, economists and entrepreneurs. Thus, for instance, U.S. professor of business and finance R. Peavler (2010) states that the role of financial analysis in organization management is very large. To make strategically sound decisions, entrepreneurs must know how to analyse financial reports with an aim to understand what changes have happened and how these changes impact the financial results of the company.

U.S. finance expert L. Rudnicka (2009) asserts that with the help of financial analysis company management can make objective and well-founded conclusions on the current financial situation in the enterprise, therefore, it is equally important for large, as well as small companies.

Scientist P. Atrill (2006) also stresses that financial analysis is especially important for managers to make decisions in different spheres, such as planning of earnings, management of working capital, dividend policy etc.

Papers on the role of financial analysis in corporate management decisionmaking are also published regularly in economic journals, which prove that the importance of analysis in modern world is still increasing. Thus, for example, papers that are accessible in portal "Financial analysis papers" note that nowadays business is being subjected to fast changing market conditions, and companies regularly need to modernize their products, continuously improve the level of management, which demands that thorough financial analysis is performed (Financial analysis papers, 2009).

Russian economist V. Bocharov (Бочаров, 2009) states that financial statement analysis serves as a basis for 
management decision-making - based on the results of evaluation the managers of the company make decisions with regard to company long-term financing (the investing of capital in projects and valuable securities), short-term financing (the supplementation of current assets), paying dividends, the mobilization of reserves of economic growth etc. The financial expert A. Sinyagin (Синягин, 2005) also believes that the main aim of financial analysis from the point of view of managers is the working out of recommendations for successful company operations in the future.

Therefore, by investigating the notion of financial analysis, one can detect that, despite of the different opinions on the definition and place in science of financial analysis, all the leading economists agree that without quality analysis an effective company management is not possible. Having carried out the research it has become clear that the role of financial analysis in enterprise controlling is increasing, in other words, it is transforming and becoming an integral part of any financial activities. Analysis has a noticeable role in all levels of management - strategic, tactical, as well as operational, and it is a component that can prevent the company from going bankrupt.

In Latvia, in the beginning of nineties, when economic restructuring took place and businesses were started, the importance of financial analysis was rarely realized. The majority of companies did not conduct proper calculations and substantiations, put forward aims that contradicted the financial condition, and therefore, lost their positions in the market. Now, there is an understanding of the significant role of financial analysis, and this, possibly, will influence business in a positive way.
However, the authors of the paper believe that the process of management decision-making, which is based on financial analysis, is more of an art than a science. There are several subjective factors. The results of financial analysis is only the material base for decision-making but much depends on the manager himself or herself - his or her experience, intuition, intellect, logic, the ability to take risks, character, the management talent etc. But one must add that in current circumstances it is very hard and maybe even impossible for entrepreneurs to achieve excellent results or maintain them for a long time without well-compiled financial analysis.

\section{Conclusions}

Studying the interpretations of several authors on the notion of financial analysis, the authors of the paper have concluded that there are different opinions on what is financial analysis, and that with this notion analysis of financial statements and analysis of financial condition is often understood. To authors' minds, the best interpretation of financial analysis is that it is a process based on investigation of data (indicators that characterise the financial position and past operating performance of a company) with the aim of evaluation of company development prospects.

Comparing the interpretations, the authors have arrived at a conclusion that equalising the notions of financial analysis of analysis of financial condition is not well-founded. The concept of financial analysis is wider; therefore, the terms can not be used as synonyms. The authors offer the approach where analysis of financial condition is part of the analysis of business activity or financial analysis. 
Analysing the term of financial statement analysis, one can conclude that it means the same thing as financial analysis, therefore, one can use the terms as identical. However, the title is not correct because according to the definition a thought might arise that the structure, contents etc. of financial report are being evaluated. This title - financial statement analysis - reflects the main aim of analysis (management decision-making) to a lesser degree; therefore, financial analysis is the most appropriate title for this research.

Based on the analysis of different sources of literature conducted during the preparation of this paper, one can conclude that there are different approaches to the place of financial analysis in economic science. Some experts believe that it is an important part financial management, others - that financial analysis is a separate science. The authors of this paper interpret financial analysis as an element of financial management because company management uses different methods of analysis mainly to successfully manage company financial resources. Financial analysis is sought after among creditors and investors, in courts and other state institutions to make well-founded decisions. The main goal of financial management is to maximise company owners' wealth.

According to the aim and tasks of financial analysis one can infer that financial analysis has a very important role in successful functioning of the enterprise. Regardless of the different opinions on the definition of financial analysis and its place in science, all leading economists agree that efficient corporate management is not possible without analysis that is conducted qualitatively. The role of financial analysis has been transformed as the business world has changed too, gaining new standards and possibilities.

Investigating the methods of conducting financial analysis (with the term "methods" the authors describe an aggregated notion, which includes different models, methods and approaches to conducting financial analysis), one can conclude that nowadays financial analysis carried out taking into consideration different models to provide the full picture of company's financial position. Modern qualified analysis needs transformation and unification of existing methods, in order to achieve better results and have long-term profit. The authors put forward their own methods of conducting financial analysis that include descriptive, predicative and normative models, and which can be used to evaluate operations of multiple companies. The methods help in clarifying the situation in a company and allow drawing up correct conclusions that later on will lead to the necessary decisions.

The authors of the paper believe that the process of management decisionmaking, which is based on financial analysis, is more of an art than science. There are several subjective factors. The results of financial analysis is only the material base for decision-making but much depends on the manager himself or herself his or her experience, intuition, intellect, logic, the ability to take risks, character, the management talent etc. However, in current circumstances it is very hard and maybe even impossible for entrepreneurs to achieve excellent performance or maintain it for a long time without well-compiled financial analysis. 


\section{References}

1. Accounting for managers. (2011). Horizontal analysis or trend analysis. Internet access: <http://www.accountingformanagement.com/ horizontal_analysis_or_trend_analysis.htm >, [accessed May 11, 2012].

2. Article from e-encyclopaedia (2011a). Финансовый анализ. Internet Access: <http:// ru.wikipedia.org/wiki>, [accessed December 22, 2011].

3. Article from e-encyclopaedia. (2011b). Financial analysis. Internet access: <http://en.wikipedia. org/wiki/Financial_analysis $>$ [accessed December 22, 2011].

4. Atrill, P. (2006). Financial management for decision makers. Harlow: Pearson Education.

5. Bernstain, L. A. (2002). Financial Statement Analysis: Theory, Application and Interpretation. 6th ed. McGraw Hill.

6. Bowlin, O. D., Martin, J. D., Scott, D. F. (1990). Guide to financial analysis. 2nd ed. McGraw Hill Inc.

7. Brigham, J. F., Gapenski, E. F. (1997). Financial Management: Theory and Practice. 8th ed. The Dryden Press / Harcourt Brace College.

8. Bushman, M. (2007). Financial Statement Analysis Methods: Horizontal vs. Vertical Analysis. Internet access: <http://voices.yahoo. com /financial -statement-analysis-methodshorizontal-vs-328159.html>, [accessed May 02, 2012].

9. Cheng, A., Yang, S. S. M. (2003). The Incremental Information Content of Earnings and Cash Flows from Operations Affected by Their Extremity // Journal of Business Finance \& Accounting. Volume 30, Issue 1-2. doi: 10.1111/14685957.00484.

10. Clausen, J. (2010). Accounting- vertical analysis. Accounting. Internet access: $<$ http://james-clausen. suite101.com/accounting101-basics---verticalanalysis-a204428>, [accessed May 11, 2012].

11. Clubb, C. D. B. (1995). An Empirical Study of the Information Content of Accounting Earnings, Funds Flows and Cash Flows in the UK // Journal of Business Finance \& Accounting. Vol. 22, No. 1. doi: 10.1111/j.1468-5957.1995.tb00670.x.

12. E-how money. (2012). Importance of cash flows. Internet access: <http://www.ehow.com/ about_6162338_importance-statement-cashflows.html>, [accessed May 07, 2012].

13. Experts Column. (2009). Importance of Cash Flows statement (A Brief Note). Internet access: <http://expertscolumn.com/content/ importance-cash-flows-statement-brief-note $>$, [accessed May 14, 2012].

14. Financial analysis papers. (2009).Enterprise Financial Analysis of Problems and Solutions. Internetaccess:<http://eng.hi138.com/?i79546>, [accessed May 16, 2012].

15. Helfert, E. A. (2003). Techniques of Financial Analysis: A Guide to Value Creation. 10th ed. -McGraw Hill.

16. Hottman, S. (2011). 5 tips for forecasting and maintaining cash flow. Inc. Internet access: <http://www.inc.com/guides/201110/5-tipsfor-forecasting-maintaining-cash-flow.html>, [accessed May 07, 2012].

17. Javed, R. (2009). Financial statement analysis. Internet access: <http://www.articlesbase. com/accounting-articles/financial-statementanalysis-729032.html>, [accessed March 20, 2012].

18. Kulkarni, A. (2012). Understanding horizotal analysis. Buzzle.com. Internet access: <http:// www.buzzle.com/articles/horizontal-analysis. html>, [accessed March 20, 2012].

19. Lee, T. A., Ingram, R. W., Howard, T. P. (1999). The Difference between Earnings and Operating Cash Flow as an Indicator of Financial Reporting Fraud. Contemporary Accounting Research. Volume 16, Issue 4. doi: 1111/j.1911-3846.1999.tb00603.x.

20. Lorette, K. (2012). Importance of Factor Analysis in Marketing. Small Business. Internet access: <http://smallbusiness.chron.com/ importance-factor-analysis-marketing-1698. html>, [accessed May 11, 2012].

21. McLeay, S., Kassab, J., Helan, M. (1997). The Incremental Information Content of Accruals: Evidence Based on the Exponential Smoothing of Levels and Trends in Pre-Tax Earnings, Funds Flow and Cash Flow. Journal of Business Finance \& Accounting, Vol.24, Nos. 7 \& 8. doi: 10.1111/1468-5957.00156.

22. Peavler, R. (2010). Financial statement analysis for your small business firm. Business finance. Internet access: <http://bizfinance.about.com/ od/yourfinancialposition/a/finstateanal.htm>, [accessed April 21, 2012].

23. Rudnicka, L. (2009). Limitations of financial ratio analysis. Internet access: <http:// ezinearticles.com/?Limitations-of-FinancialRatio-Analysis\&id=3481750>, [accessed April 21, 2012]. 
24. Saylor, R. (2008). The Williams Companies, Inc: Key Financial Information and P/E Ratio. Internet access: <http://voices.yahoo.com/ the-williams-companies-inc-key-financialinformation-1701871.html?cat=3>, [accessed May 23, 2012].

25. Sharpe, W. F., Alexander, G. J., Bailey, J. V. (1998). Investments. 6th ed. Prentice Hall.

26. Siddiqui, S. M. (2007). Limiting factor analysis. Ezine articles. Internet access: $<$ http://ezinearticles.com/?Limiting-FactorAnalysis\&id=709587>, [accessed May 05, 2012].

27. Subatnieks, K. (2007). Promocijas darba kopsavilkums. Naudas plūsmasi zmantoša nauzñē muma finanšu analīzē. Rīga. Internet access: <http://www3.acadlib.lv/greydoc/ Subatnieks_disertacija/Subatnieks.pdf $>$, [accessed April 10, 2012].

28. Šneidere, R. (2009). Finanšu analīzes metodes uzṇēmuma maksātnespējas prognozēšanai. Rīga: Lietišķās informācijas dienests.

29. Uzochukwu, I. F. (2010). The Role Of Ratio Analysis In Business Decisions. Internet access: $<$ www.caritasuni.edu.ng/.../management/acc3>, [accessed May 05, 2012].

30. Van Horne, J. C. (1996). Fundamentals of financial management. 7th ed.- Prentice Hall.

31. Балабанов, И. Т. (2002). Финансовый анализ и планирование хозяйствующего субъекта. Москва: Финансыистатистика.

32. Балжинов, А. В., Михеева, Е. Б. (2012). Анализ и диагностика финансово хозяйственной деятельности предприятия. Internet access: $<$ http://afdanalyse.ru/publ/finansovyj_analiz/1/ faktornyj_analiz_1/11-1-0-42>, [accessed May 02, 2012].

33. Басовский, Л. Е., Лунёва, А. М., Басовский, А. Л. (2005). Экономический анализ. Журнал„Корпоративный менеджмент”. Internet access: <http://www.cfin.ru/finanalysis/ reports/economic_analysis.shtml $>, \quad$ [accessed February 26, 2012].

34. Бланк, И. А. (2004). Финансовый менеджмент. 2-е изд. Киев: Ника Центр.

35. Бородина, Е. И. (2011). Финансовый анализ в системе менеджмента организации. Internet access: <http://vertexglobal.ru/main/articles/ finansovyj_analiz_v_sisteme_menedzhmenta_ organizaci/>, [accessed March 21, 2012].

36. Бочаров, В. В. (2009). Финансовый анализ. Краткий курс. 2-е изд. СПб: Питер.
37. Ефимова, О. В. (2012). Финансовый анализ. Журнал „Финансы и кредит”. Internet access: <http://www.finkredit.com/analiz1.html>, [accessed February 08,2012].

38. Жилкина, А. Н. (2005). Диссертация: Повышение качества управления финансами предприятия средствами финансового анализа. Internet access: <http://www. dissercat.com/content/povyshenie-kachestvaupravleniya-finansa mi-predpriyatiyasredstvami-finansovogo-analiza $>$ [accessed March 20, 2012].

39. Ковалёв, В. В. (2000). Финансовыйанализ:Уп равлениекапиталом.Выбор инвестиций. 2-е изд. Москва: Финансыистатистика.

40. Ковалёв, В. В. (2002).Финансовый анализ: методы и процедуры. Москва: Финансы и статистика.

41. Крылов, С. И. (2010). Показатели рыночной активности открытого акционерного общества и порядок их анализа. Финансовая аналитика. Internet access: <http://finanal. ru/001/pokazateli-rynochnoi-aktivnostiotkrytogo-aktsionernogo-obshchestva-iporyadok-ikh-analiza>, [accessed May 23, 2012].

42. Лиференко, Г. Н. (2005). Финансовый анализ предприятия. Москва: Экзамен.

43. Мухаметшин, А. Т., Антипов, А. В. (2012). Коэффициентный метод анализа финансового состояния: сложности и ограничения. Журнал „Анализ финансового состояния предприятия. Internet access: <http://afdanalyse.ru/news/ koehfficientnyjmetod_analiza/2011-06-26161>, [accessed May 10,2012].

44. Новопашина, Е. (2008). Практика оценки финансового состояния хозяйствующего субъекта с учетом мирового опыта. Internet access: <http://www.unilib.org/page. php?idb $=1$ \&page $=000300>$, [accessed April 26, 2012].

45. Поляк, Г. Б. (2009). Финансовый менеджмент. - Москва: Wolters Kluwer.

46. Русак, Н. А. (1999). Анализ хозяйственной деятельности в промышленности. Минск: Вышэйш. шк.

47. Санникова, И. Н., Стась, В. Н., Эргардт, О. И. (2003). Учебное пособие: Комплексный финансовый анализ. Internet access: <http:// www.econ.asu.ru/lib/uch_ergardt.pdf>, [accessed February 15, 2012]. 
48. Синягин,А.(2005).Цельизадачифинансового анализа. Журнал „Рынокценныхбумаг”. Internet access: <http://www.cfin.ru/finanalysis/ ru_specifics.shtml>, [accessed May 02, 2012].
49. Федосеев, В. В., Гармаш, А. Н. и др. (1999). Экономико-математические методы и прикладныемодели. Москва: ЮНИТИ.

The paper submitted: November 2, 2012

Prepared for publication: December 17, 2012

Elvīra ZELGALVE, Anastasija ZAHARČENKO

\section{FINANSINĖS ANALIZĖS VAIDMENS POKYTIS İMONÉS VALDYME}

\section{S a n t ra u k a}

Straipsnio autoriai atliko išsamų finansinès analizès sąvokos tyrimą ekonomikos teorijoje, atskirdami tokias sąvokas kaip „finansinès ataskaitos analizë”, „finansinès padèties analizè”, „finansinè analizè". Buvo prieita išvados, kad negalima laikyti tokių sąvokų kaip „finansinès būsenos analizè" ir „finansinè analizë" adekvačiomis, nes finansinès analizès apibrèžimas yra kur kas platesnis. Finansinès ataskaitos analizè ir finansinès analizès terminai gali būti naudojami kaip adekvatūs, tačiau reikia pastebèti, kad kartais pirmoji sąvoka yra maišoma su finansinès ataskaitos struktūros, o ne rodiklių vertinimais. Taip pat autoriai išanalizavo finansinès analizès vietą ekonomikos moksle, susiedami ją su vienu svarbiausiu finansinio valdymo veiksniu. Atlikus tyrimą išsiaiškinta, kad finansinès analizès reikšmè įmonès valdyme auga, keičiasi ir tampa finansinès veiklos dalimi. Straipsnyje išskiriami ir pagrindiniai finansinès analizès tikslai, dalys ir uždaviniai.

Šiandieninèse rinkos sąlygose, įmonès finansinẻ būsena ir veiksmų efektyvumo vertinimas gali būti laikomi finansinès politikos dalimis, todèl pagrindinè ịmonés užduotis yra orientuotis ị finansų valdymo kokybę, kuri remiasi finansinès analizès rezultatais rinkos sąlygomis. Autoriai įrodè, kad šiuolaikinès analizès metodams reikia pokyčių ir unifikacijos.

Autoriai pateikè finansinès analizès metodus, apibendrindami juos loginèje schemoje. Ją sudaro aprašomojo modelio naudojimas: apskaitos ataskaitu skaitymas, horizontalioji ir vertikalioji ịvairių rodiklių analizè, finansinių santykių (stabilumo, likvidumo, pelningumo) analizè, finansų rinkos analizè, veiksnių analizè, palyginamoji analizè; nuspèjamasis modelis (bankroto, pinigų srautu, ekonominio pelningumo spejimai); ir normatyvinis modelis. Šie metodai leidžia ịvertinti ịmonès finansinès būklès rodiklius ir dinamiką, pateikti detalę įmonès finansinès būklès informaciją, ivertinti jos galimybes generuoti piniginius srautus, suprasti kaip įmonès veiksmai yra vertinami vertybinių popierių rinkoje, išsiaiškinti, kurie veiksniai teigiamai ar neigiamai veikia finansinius indeksus ir išmatuoti ateities vystymosi perspektyvas.

Dirbant pagal šią schemą galima atlikti išsamią įmonès finansinès veiklos analizę, kuri leis ịvertinti veiklą ir identifikuos valdymo sprendimų poreiki.

Tyrimas autoriams leido konstatuoti, kad finansinè analizè gali būti naudojama kaip trumpo arba ilgo laikotarpio ekonominių sprendimų priemimų ịrankis, vertinant valdymo kokybę ar numatant ateities rezultatus. 